Research Article

Malays. j. med. biol. res.

\title{
Intercropping System of Maize with Different Winter Vegetables
}

\author{
M. H. Hossain ${ }^{1}$, Shamal Kumar Bhowal' ${ }^{2}$, A. S. M. M. R. Khan ${ }^{3}$
}

${ }^{1}$ Senior Scientific Officer, On- Farm Research Division, Bangladesh Agricultural Research Institute, Comilla, BANGLADESH

${ }^{2}$ Scientific Officer, On- Farm Research Division, Bangladesh Agricultural Research Institute, Comilla, BANGLADESH

${ }^{3}$ Chief Scientific Officer, On- Farm Research Division, Bangladesh Agricultural Research Institute, Gazipur, BANGLADESH

*Correspondence (Email):

shamal.bau@gmail.com

\begin{abstract}
The experiment was conducted at farmers' fields of Hqripur in Dauadkandiupzilla underOn- Farm Research Division of Bangladesh Agricultural Research Institute, Comilla during the rabi seasons of 2012-13 and 2013-14 toevaluate the performance of maizeunder intercropping with different winter vegetables. The experiment comprised of four treatments viz., Maize + Spinach, Maize + Red amaranth, Maize + Coriander and Sole maize with four replications. Results revealed that each of maize- vegetables intercropping combinations showed superior in terms of gross return, net return, BCR and Maize equivalent yield (MEY) over sole cropping of maize. The highest grain yield of maize $\left(9.61 \mathrm{t} \mathrm{ha}^{-1}\right)$ was obtained fromMaize + coriander due to the highest contribution of yield contributing characters and lowest $\left(7.8 \mathrm{tha} \mathrm{h}^{-1}\right)$ yield was received from the treatment of maize + red amaranth intercropping system, where the sole maize produced second highest yield.The highest Maize equivalent yield $\left(12.85 \mathrm{t} \mathrm{ha}^{-1}\right)$, gross return (Tk. $\left.128500 \mathrm{ha}^{-1}\right)$, net return (Tk. $80080 \mathrm{ha}^{-1}$ ) and BCR (2.65) were found in the intercropping system Maize + Spinach which indicated the advantage of intercropping over the sole Maize cropping.
\end{abstract}

Key words: Intercropping, Maize (Zea mays), vegetables, profitability

\begin{tabular}{ll}
\hline 12/31/2016 & Source of Support: None, No Conflict of Interest: Declared \\
\hline $\begin{array}{l}\text { This article is is licensed under a Creative Commons Attribution-NonCommercial 4.0 International License. } \\
\text { Attribution-NonCommercial (CC BY-NC) license lets others remix, tweak, and build upon work non-commercially, and although the new works must also } \\
\text { acknowledge \& be non-commercial. }\end{array}$ & CC) 8 SY
\end{tabular}

\section{INTRODUCTION}

Maize (Zea mays) belongs to the family Grammies a versatile photo insensitive crop. Maize is a third important cereal crop in our country. It is more nutritious than rice. Bangladesh has the opportunity to increase the maize cultivation area and yield for its soil conditions, topography, and climate. It is an emerging crop in our country and growing popular day by day. It can be grown both in Rabi and Kharif season in this region and being a wide spaced crop can accommodate intercrops within the available interspaces. The growing period of maize is very long. It takes more than five months. With the introduction of high yielding seeds, its area and production have been expanding very fast. Vegetables in this regard are considered to be profitable proposition because of additional yield and higher net returns. The maize + vegetables intercropping field experiment was conducted in different locations during Rabiseason 2005-06. Findings from different locations showed that the highest maize equivalent yield was obtained from Maize + Bush bean intercropping systems at Jamalpur, Maize + Spinach at Jessore, Mymensingh and Rangpur, Maize + coriander (as vegetable) at Pabna. Maize + Red amaranth at Kushtia and Manikganj (OFRD, 2006). The association of bush bean with maize provides some $\mathrm{N}$ economy (Singh et al., 2000).Compared with corresponding sole crops, yield advantages have been recorded in many intercropping systems, including maize/soybean (West and Griffith, 1992; Ghaffarzadeh et al, 1994), Sorghum/soybean (Elmore and Jackobs, 1986), wheat/mungbean (Chowdhury and Rosario, 1994), wheat/chickpea (Mandal et al, 1996), barley/ medic (Moynihan et al, 1996), canola/soybean (Ayisi et al., 1997), maize/ lucerne (Smith and Carter, 1998), maize/Feb bean (Li et al., 1999) etc. In maize/soybean strip intercropping, West and Griffith (1992), observed a $26 \%$ 
increase in maize and a $27 \%$ yield reduction in soybean border rows in eight rows alternating strips in Indiana. Ghaffarzadeh et al, (1994) recorded that strip intercropping had 20-24 \% greater maize yields and $10-15 \%$ smaller soybean yields in adjacent border rows in the maize/soybean intercropping in Iowa. Intercropping is widely practiced by the farmers of Bangladesh. Generally legumes in association with non-legumes not only helps in the utilization of the nitrogen being fixed in the current growing season, but also helps in residual nutrients build up of the soil. However, the benefit accrued from intercropping may vary according to the nature and type of intercrops and their population densities. Therefore, it is necessary to identify maize-based productive systems for higher monetary returns in Comilla region.So, here is ample scope for intercropping with short duration vegetables with maize in the intermediate period without hampering the main yield of maize. In view of this a study was conductedto evaluate the performance of maize under intercropping with different short dated vegetablesviz. Spinach, Amaranth and Coriander for selectionof suitable crop for intercropping with maize and to increase the cropping intensity, as well asincrease the farmers' income.

\section{Materials AND Methods}

The experiment was conducted in the farmer's field of Haripur, Daudkandiupazilla in Comilla district during the two consecutive Rabi seasons of 2012-13 and 2013-14. The experiment was laid out in Randomized Complete Block (RCB) Design withfour replications. The individual plot size was $6.0 \mathrm{~m} \times 3.2 \mathrm{~m}$ whereblock to block and plot to plot distances were $1.5 \mathrm{~m}$ and $1.0 \mathrm{~m}$, respectively. BARI developed new hybrid variety BARI Hybrid Maize 9 was sown at the rate of $25 \mathrm{~kg} \mathrm{ha}^{-1}$ on $1^{\text {st }}$ week of Decemberin this experiment. Seeds were treated with Provax-200 for controlling seed and soil borne diseases. The soil of the experimental plot was clay loam. Seeds were sown in line maintaining $60 \mathrm{~cm}$ line to line and $20 \mathrm{~cm}$ seed to seed distance.Fertilizers were applied at the rate of 250-55-110-40-5 and $2 \mathrm{~kg}$ per ha of N, P, K, S, Zn and B in the form of Urea, Triple Super Phosphate, Muriate of Potash, Gypsum, Zinc Oxide and Boric acid, respectively (FRG, 2005). Half of Urea and all other fertilizers were applied during final land preparation. The rest amount of Urea was top dressed at 30 Days after sowing (DAS) and irrigation was done as and when necessary. To control the disease and pest,Bavistin @ $1 \mathrm{~g} \mathrm{~L}^{-1}$,Karate $2.5 \mathrm{EC}$ (Lamdacyhelothrin) @ $1.5 \mathrm{ml} \mathrm{L}^{-1}$ and Dasban 20 EC (Chloropyriphos) @ $4 \mathrm{ml} \mathrm{L}$ ${ }^{1}$, respectively were applied in the experimental farmer's field. Four treatments were tested in this experiment. The treatments were (i) Maize + Indian spinach, (ii) Maize + Red amaranth (iii) Maize + Coriander and (iv) Sole maize. The seeds of vegetables were sown $20 \mathrm{~cm}$ aparti.e. two lines of vegetables in between two lines of maize. The weeding and earthen up were done 38 days after sowing of Maize. The vegetables of this experiment were harvested from last week of December and continue up to the $2^{\text {nd }}$ week of January at each of the year and Maize was harvested 142 days after sowing on 3rd week of April. Data on plant height, ear height, length and breadth of the cob, individual cob weight, number and weight of seeds per cob, 1000 seeds weight and grain yield per hectare were recorded for data analysis. Ten cobs were randomly harvested from each plot, which was later converted into ton per hectare. The recorded data were analyzed following MSTATC program (Gomez and Gomez, 1984). Maize equivalent yield (MEY) and BCR were calculated to ascertain the efficiency of intercropping. Maize equivalent yield was calculated by converting the yield of intercrops to the yield of Maize on the basis of prevailing market prices of individual crops. Economic analysis on the basis of net monetary return was performed to evaluate the intercropping system.

Maize Equivalent Yield was calculated after Bandyopadhyay (1984):

Maize Equivalent Yield (MEY) = Yield of Intercrop $\left(\mathrm{Kg} \mathrm{ha}^{-1}\right) \times$ Price of Intercrop $\left(\mathrm{Tk} \mathrm{Kg} \mathrm{Kg}^{-1}\right)$

Price of Maize $\left(\mathrm{Tk} \mathrm{Kg}^{-1}\right)$

\section{RESULTS AND Discussion}

Yield and yield contributing characters of Maize

Plant characters and yield attributes of BARI Hybrid Maize 9 in maize- vegetable intercropping system were presented in Table 1.The highest plant $(212.75 \mathrm{~cm})$ and ear height $(115.40 \mathrm{~cm})$ was recorded from sole maize followed by maize + coriander and the lowest $(115.40 \mathrm{~cm}$ and $96.60 \mathrm{~cm})$ from maize + spinach intercropping system. It was revealed that in case of plant height, there was no significant difference among the treatments except sole maize. Maize + red amaranthsystem gave statistically similar ear height with maize + coriander. The maximum individual weight of cobs (154.09 g) was recorded from maize (sole) followed by maize + coriander and minimum $(122.24 \mathrm{~g})$ from maize + red amaranth. The highest length $(16.25 \mathrm{~cm})$ and number $(527.88)$ of seeds per cob were obtained from the treatment maize (sole) followed by maize + spinach and the lowest $(14.25 \mathrm{~cm}$ and $405.5 \mathrm{no}$.) from maize + red amaranth intercropping system. The treatment maize + coriander produced the highest weight (149.13 g) of seeds per cobs that was statistically similar with maize + spinach and the lowest $(113.65 \mathrm{~g})$ from maize + red amaranth. In case of weight of 1000 seeds, the height $(293.85 \mathrm{~g})$ and the lowest $(259.12 \mathrm{~g})$ weight of 1000 seeds were produced by the treatment Maize + coriander and maize + red amaranth respectively. All the treatments produced statistically similar results except maize + coriander. It was revealed that, Maize + coriander intercropping system 
produced the highest maize yield $\left(9.61 \mathrm{t} \mathrm{ha}^{-1}\right)$ and the lowest $\left(7.8 \mathrm{tha}^{-1}\right)$ from Maize + red amaranth (Fig. 1).The treatments, Maize + Spinach produced the second highest yield that was statistically similar with sole maize and maize + red amaranth. Morris and Garrity (1993) also support the yield advantages in intercropping combinations who mentioned that there are close relationships between yield advantage and nutrient uptake.

\section{Yield of Intercrops (Vegetables)}

The highest average yield of intercrops $\left(7.36 \mathrm{t} \mathrm{ha}^{-1}\right)$ was found from the Maize + Spinach intercropping system whereas the lowest average yield $\left(0.78 \mathrm{t} \mathrm{ha}^{-1}\right)$ was found in Maize + Coriander intercropping system. (Fig. 1)

\section{Maize Equivalent Yield (MEY)}

Maize equivalent yields in the intercrops were significantly higher than the sole crops. The pooled data showed that the highest average Maize equivalent yield of $12.85 \mathrm{t} \mathrm{ha}^{-1}$ was obtained from Maize + Spinach intercropping systemsfollowed by maize + red amaranth and maize + coriander, which was $48.38 \%$ higher than the sole crop of Maize(Fig. 1). The results indicated that cereal (Maize) - vegetable intercropping could bring more benefit to farmers over sole maize. The increment of total production by intercropping than sole cropping was also reported by Rao and Willey (1980); Umraniet. al (1984); Bandhyopadhyay (1984); Basaket.al(2006) and Bhowal et. al (2014).

\section{Cost and benefit analysis}

Total cost, gross return,net return and BCR of maize-vegetable intercropping systemswere shown in Table 2. The overall total cost was less in sole maize than those of intercrop combination. Though the intercropping system Maize + Spinachgave comparatively lower yield of maize but it gave the highest gross return (Tk.128500 ha-1) and net return (Tk.80080 ha ${ }^{-1}$ ) as well as highest BCR (2.65) over sole cropping of maize. The second highest gross return (Tk.123200 ha ${ }^{-1}$ ) and net return (Tk. 75380 ha $^{-1}$ ) was found in Maize + Red Amaranth intercropping system (Table 2).Many researchers also documented higher gross margin or net return in intercropping system than sole crop (Razzaque et. al., 2007; Alam et al., 2008; Bhuiyanet al., 2013; and Farhadet al., 2014.Uddinet al. (2009) also documented that all the Maize-vegetables intercropping system in the hilly areas of Bangladesh showed higher BCR than sole maize, which also strongly supports the above findings.

Table 1: Plant and yield contributing characters of BARI Hybrid Maize 9 at farmer's field of Daudkandi, Comilla during the rabi season of 2012-13 and 2013-14 (Pooled)

\begin{tabular}{|c|c|c|c|c|c|c|c|}
\hline Treatment & $\begin{array}{c}\text { Plant } \\
\text { height }(\mathrm{cm})\end{array}$ & $\begin{array}{l}\text { Ear height } \\
(\mathrm{cm})\end{array}$ & $\begin{array}{l}\text { Individual weight } \\
\text { of } \mathrm{cob}(\mathrm{g})\end{array}$ & $\begin{array}{l}\text { Length of } \\
\text { cobs }(\mathrm{cm})\end{array}$ & $\begin{array}{c}\text { No. of } \\
\text { seeds } \text { cob }^{-1}\end{array}$ & $\begin{array}{c}\text { Wt. of seeds } \\
\mathrm{cob}^{-1}(\mathrm{~g})\end{array}$ & $\begin{array}{l}\text { Wt. of } 1000 \\
\text { seeds }(\mathrm{g})\end{array}$ \\
\hline Maize + Spinach & 199.83 & 107.35 & 138.66 & 15.35 & 486.15 & 145.48 & 271.46 \\
\hline Maize + Red Amaranth & 203.85 & 97.95 & 122.24 & 14.25 & 405.5 & 113.65 & 259.12 \\
\hline Maize + Coriander & 207.45 & 96.60 & 149.67 & 15.78 & 474.15 & 149.13 & 293.85 \\
\hline Maize (Sole) & 212.75 & 115.40 & 154.09 & 16.25 & 527.88 & 137.58 & 268.59 \\
\hline CV (\%) & 2.57 & 1.74 & 5.74 & 4.74 & 5.90 & 3.13 & 5.04 \\
\hline LSD (0.001) & 8.47 & 2.90 & 12.96 & 1.12 & 44.70 & 6.83 & 22.02 \\
\hline
\end{tabular}

Table 2: Cost and Return analysis of maize intercropping with vegetablesat farmer's field of Daudkandi, Comilla during the Rabi season of 2012-13 and 2013-14 (Pooled)

\begin{tabular}{|l|c|c|c|c|}
\hline Treatment & Gross return $\left(\mathrm{Tk}^{\mathrm{h}} \mathrm{ha}^{-1}\right)$ & Total cost $\left(\mathrm{Tk} . \mathrm{ha}^{-1}\right)$ & Net return $\left(\mathrm{Tk} . \mathrm{ha}^{-1}\right)$ & $\mathrm{BCR}$ \\
\hline Maize + Spinach & 128500 & 48420 & 80080 & 2.65 \\
\hline Maize + Red Amaranth & 123200 & 47860 & 75380 & 2.57 \\
\hline Maize + Coriander & 111700 & 44650 & 67050 & 2.50 \\
\hline Maize & 86600 & 43980 & 42620 & 1.96 \\
\hline
\end{tabular}

Unit $\left(\mathrm{Kg}^{-1}\right)$ price of Maize: Tk. 10, Spinach: Tk.9, Red amaranth: Tk.10 and Leaf of Coriander: Tk. 30

\section{CONCLUSION}

Considering the yield and above mentioned discussion it can be concludedthat all the maize-vegetable intercropping system showed higher benefit but spinach and red amaranth with maize was found more profitable compared to sole maize.

\section{FARMERS' AsSESSMENT}

Farmers' showed their keen interest for growing spinach or red amaranth with maize because they get additional income from the intercrops. Short duration vegetables (spinach or red amaranth) can be easily cultivated to the uncovered area of maize (at early stage) without hampering the main yield of maize. Moreover, additional income was also obtained from the intercrops. 


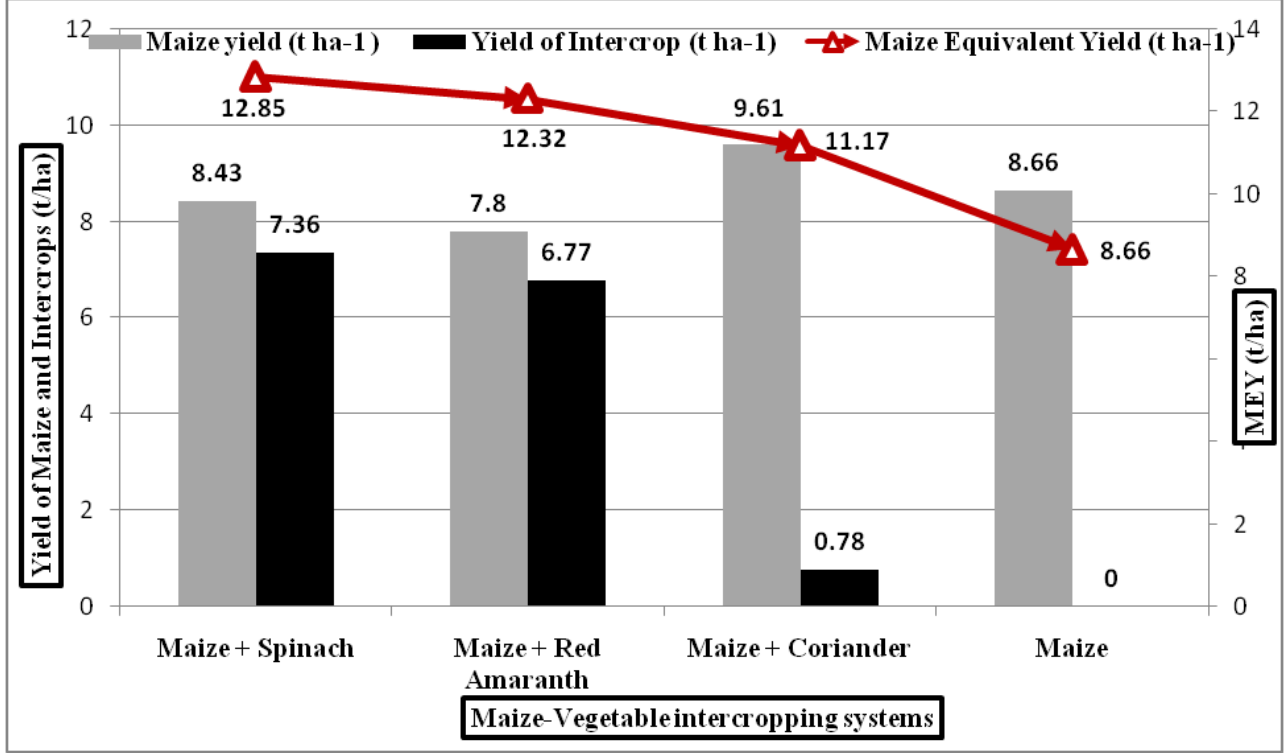

Fig. 1: Comparison of Maize and Intercrop (vegetables) Yield with Maize Equivalent Yield (MEY) in Maizevegetable intercropping system

\section{REFERENCES}

Alom MS, Paul NK, Quayyum MA. 2008. Performance of hybrid maize (Zea mays L.) under intercropping systems with mungbean in different planting methods. SAARC J. Agri. 6: 73-82.

Ayisi K. K., Putman, D. H., Vance, C. P., Russelle, M. P., Allan, D. L., 1997. Strip intercropping and nitrogen effects on seed, oil and protein yields of canola and soybean. Agron. J. 89, 23-29

Bandyopadhyay, S. K. 1984. Nitrogen and water relations in grain sorghum legume intercropping systems. Ph. D. Dissertation, Indian Agricultural Research Institute (IARI), New Delhi- 110012, India.

Basak, N. C., S. M. A. Hossain, N. Islam, N. I. Bhuiyan.2006. Intercropping wheat with groundnut at variable plant population.Bangladesh J. Agril. Res. 31(2):207-215.

Bhowal, S. K., M. M.U. Chowdhury, M. S. Bhuiyan, A. H. M. A. Faisal, I. S. M. Farhad and S. K. Bhowmik. 2014. Yield and Yield Attributes of Lentil (Lens Esculenta) as a Mixed Crop with Mustard (Brassica Campestris). Sci. Agri. 4 (2), 76-79

Bhuiyan MS, Bhowal SK, Farhad IS, Chowdhury MMU, Amin M. 2013. Intercropping soybean with kaon in varying plant population in the coastal area of Noakhali region.Bangladesh Agron. J. 16(1): 81-86

Chowdhury, M. K., Rosario, E. L., 1994. Comparison of nitrogen, phosphorus and potassium utilization efficiency in maize/mungbean intercropping.J. Agric. Sci. Camb. 122, 193-199

Elmore, R. W., Jackobs, J. A., 1986. Yield and nitrogen yield of sorghum intercropped with nodulating and non-nodulating soybeans. Agron. J. 78, 780-782

Farhad I S M, Chowdhury M M U, Bhowal S K, Choudhury A K, Khan ASMMR. 2014. Chilli - Garlic Intercropping System In Coastal Saline Area. App. Sci. Report. PSCI Publications. 2 (2): 47-50.

Fertilizer Recommendation Guide (FRG), 2005. Bangladesh Agricultural Research Council.Farmgate.Dhaka.PP.

Ghaffarzadeh, M., Prechac, F. G., Cruse, R. M., 1994.Grain yield response of corn, soybean and oat grown in a strip intercropping system.Am. J. Alternative Agric. 9, 171-177

Gomez, K.A. and Gomez, A.A. 1984. Statistical Procedures for Agricultural Research.Intl.Rice Res. Inst. Philippines. pp. 187-233.

Li, L., Yang, S. C., Li, X. L., Zhang, F. S., Christie, P., 1999. Interspecific complementary and competitive interactions between intercropped maize and feba bean.Plant and soil.212 (2). 105-114

Mandal, B.K., Das, D., Saha, A., Mahasin, M., 1996. Yield advantage of wheat(Triticumaestivum) and chickpea(Cicerarietinum)under different spatial arrangements in intercropping. Indian J. Agron. 44(1), 17-21.

Morris, R. A., Garrity, D.P., 1993. Resource capture and utilization in intercropping: non nitrogen nutrients. Field Crops Res. 34, 319-334

Moynihan, J. M., Simmons, S. R., Sheaffer, C.C., 1996. Intercropping annual medic with conventional height and semi dwarf barley grown for grain.Agron. J. 88, 823-828

OFRD, 2006. Annual report of On-Farm Research Division, 2005-06, Bangladesh Agricultural Research Institute, Joydebpur, Gazipur. pp: 291-297

Rao, M. R and R. W. Willey. 1980. Evaluation of yield stability in intercropping, sorghum rpigeon pea. Expt. Agric. 16(2): 105-116.

Razzaque MA, Rafiguzzaman S, Bazzaz MMM, Ali A, Talukdar MMR. 2007. Study on the intercropping groundnut with chilli at different plant populations. Bangladesh J. Agril. Res. 32 (1): 37-43.

Singh, D. P., N. S. Rana and R. P. Singh. 2000. Growth and yield of winter maize (Zea mays) as influenced by intercrops and nitrogen application. Indian J. Agron.45:515-519.

Smith, M. A., Carter, P. R., 1998. Strip intercropping corn and alfalfa. J. Prod. Agric. 11 (3). 345-353

Uddin, M. J., M. A. Quayyum and K. M. Salahuddin. 2009. Intercropping Of Hybrid Maize With Short Duration Vegetables At Hill Valleys Of Bandarban. Bangladesh J. Agril. Res. 34(1) :51-57

Umrani, N. N., H. S. Shinde and P. M. Dhonde. 1984. Studies on intercropping of pulses in Kharif Sorghum. Indian J. Agron. 29(1):27-30.

West, T. D., Griffith, D. R., 1992. Effect of strip intercropping corn and soybean o yield and profit. J. Prod. Agric. 5, 107-110

$$
\text { -- } 0 \text {-- }
$$

